\title{
CHRYSTOLOGIA „PASTERZA” HERMASA JAKO PROBLEM BADAWCZY
}

W dotychczasowych pracach naukowych na temat "Pasterza" Hermasa najwięcej umagl poświęcono problemowi autorstwa oraz strukturze 11terackiej tego dzieła. Jest to zrozumiałe nie tylko z uwagi na wyJatkowo trudny $i$ złozony charakter samego tekstu, ale równiez z racji ścíle metodologicznych. Bez uprzedniego bowiem rozstrzygniecia podstawowych problemów historyczno-literackich, nie spośb podjać badań w zakresie problematyki doktrynalnej. Historia badań nad "Pasterzem" Hermasa oraz postulaty metodologiczne odnośnie interpretacj1 tego dzieła zostały juz przedstawione ${ }^{1}$. Wymagaja one oczywiście dalszego rozwinięcia 1 uzupełnienia. Na ile będzie to niezbędne, zostanie to równiez dokonane w trakcie omariania interesującego nas tutaj tematu. W niniejszym artykule zamierzam poruszyé najbardziej podstawowe kwestie zwiazane z chrystologia "Pasterzan. Chodzi zwaszcza o prezentacje aktualnego stanu badań w tym zakresie oraz o sformułowanie własnych wnioskóm 1 hipotez, które zamierzam szerzej uzasadnić w przygotowywanej do druku pracy. Będzie ona próbą całościowego ujecia chrystologil "Pasterza" z uwzglednieniem kontekstu kulturowo-religijnego tego dzieła, oraz wonfrontacji z ohrystologia nowotestamentalną z jednej, a pluralizmem chrystologicznym pierwszej połowy II $w$. z drugiej strony. Dopiero $w$ tak ustawionej optyce mozna będzie pełni ocenić swolsty charakter tej chrystologil oraz jej miejsce wistoril rozwoju chrystologil kościelnej ${ }^{2}$.

1 Por. F.Szulc, Spór o "Pasterza" Hermasa, "Vox Patrum" 2/1982/ $\mathrm{z} .3,340-356$.

2 Opracowanie tego zagadnienia wydaje sie szczególnie potrzebne 1 aktualne. Od pierwszych - 1 jak dotad jedynych - monografi1 pośleconych chrystologil "Pasterza" upłynęło równo sto lat, por. A.LInk, Christi Person und Werk $1 \mathrm{~m}$ Hirten des Hermas, Marburg 1886; A.Rlbagnac, La christologie du Pasteur d'Hermas, Par18 1887 . 
Dla włáciwego postawienia samego problemu, jakim jest w tym mypadku chrystologia "Pasterzan, trzeba uprzednio rozpatrzyć dwie Pundamentalne kwestie. Do pierwszej nalezy problematyka doktrynalna tego pisma. Choć wiele jej zagadnien zostało juz opracomanych, to jednak bardzo niewiele umagi pośrięcono wzajemnym powiazantom między poszczególnymi watkani, a zwłaszcza niedostatecznie zwrócono uwage na to, ze cała problematyka doktrynalna "Pasterzan stanow1 niezwykle zróznicowany kontekst dla chrystologi1. Owzględnienie tego kontekstu wraz z okréslentea jego charakteru doktrynalnego jaw1 sie jako wazny postulat badawczy. Podejmujemy to zagadnienie w pierwszym punkcie naszych doctekan.

Kwestia druga dotyczy bezpośrednio samej chrystologil. Rodzi sie tutaj kilka pytań, wórod których najbardziej zasadnicze dotyczy ogóle mozliwości syntetycznego jej przedstawienia. Czy " przypadku "Pasterza" mamy do czynienia z kilkoma róznymi 1 zupelnie 1zolowanymi od siebie koncepcjami chrystologioznymi, czy tez mozna mówić tylko o jakiejś jednej - a moze nawet jednorodnej chrystologi1? Jak nalezałoby zatem scharakteryzowá mý́l chrystologiczna Hermasa? Czy mozna miare jednoznacznie wskazać na jej genezę oraz określić jej miejsce wóród róznorodnych nurtów chrystologicznych, Jakie rozwijaky sie w tym okresie dziejóm chrześciJaństwa? otóz $w$ drugim punkcie naszych wywodów wskazujemy na warunki 1 mozliwośol uzyskania pozytywnych odpowiedzi na te pytania.

\section{Chrystologia w kontekście problematyki doktrynalnej}

N1emal powszechnie przyjęło siz uwaźá, ze tematem głónnym dzieła Hermasa jest $p$ o $u t$ a. Zagadnienie to zostało juz bardzo szeroko 1 wnikliwie opracowane ${ }^{3}$. Dodajmy od razu, ze pokute

3 Podsumopante badań $n$ tej dziedzinie podaja: P.Galtier, Aux origines de la Pénitence, Rome 1951; B. Poschmann, Busse und Letzte Olung, w: Handbuch der Dogmengeschichte, Freiburg 1951, Bd. IV/3, 14-18; K.Rahner, Die Busslehre im Hirten des Hermas, ZKTh 77/1955/385-431; P.Knorz, Die Theologie des Hirten des Hermas/Dissertatio/, Heidelberg 1958, VIII-X, 103-110; R.Joly, In: Hermas, Le Pasteur; SCh 53 bis, Parls 1968, 22-30. Wśród uczonych wykrystalizowały si c í, stanowiska. Wediug pierwszego. Hermas gtosi jednorezowa pc it, ala wozystkich, którzy cięzko zgrzeszyli pe hrzcie 1 utracili izyska- 
traktujemy jako watek przewodni tego pisma, a nie temat główny, gdyz ten ostatni tworzy przede wszystkim eklezjologia. Hermas głos: bowiem pokute - nawrócente dla Kościoła 1 na czas budowy Kościoła, az przyjdzie Pan. Nie wchodząc w dalsze szczegóły dyskusji, nalezałoby tutaj zwróc1́́ uwage na specyficzny zwizzek nauk1 o pokucie z chrystologia. Został on trafnie dostrzezony 1 przeanalizowany przez P.Knorza na przykładzie Podobienstwa $V$ 6. Twierdzi on, ze hermasowe wezwanie do pokuty 1 nawrócenta nadało temu tekstowi charakter paranetyczny ${ }^{4}$. To spostrzezenie domaga sie jednakze dalszego rozwintęcia. $Z$ metodologicznego punktu widzenia należałoby całe to zagadnienie ująć bardziej fundamentalnie: czy chrystologie pneuma sarks stworzył Hermas specjalnie dla założonych przez siebie celów morallzatorskich, czy też raczej zistniejącej juź wcześniej koncepcj1 wydoby 1 tylko akcent paranetyczny? P.Knorz akcentuje paranetyczny charakter analizowanego tekstu tak dalece, że usuwa w cién Je-

ną wtedy niewinność 1 świętość. Dotąd takiej szansy nie było, gdyz panowal pogląd o niemoznośc1 odpuszczenia grzechów popeinionych po chrzcie. Autorytet 1 popularnośc "Pasterza" bierze się właśnie stąd, ze lagodzi on rozpowszechniony rygoryzm moralny, powołując sie przy tym na bezpośrednio uzyskane objavienie. Poglad ten /oparty o tzw. Tauftheorie/ formukowali m.in.: F.X.Funk, A. von Harnack, F.Loofs, R.Seeberg, M.Dibelius. Stanowisko przecimne opiera sie na przekonaniu, ze Hermas nie gło81 nic nowego, ani nadzwyczajnego, tylko jest wyrazicielem praktykowanej juz w Kościele pokuty, która dawała możliwość uzyskania odpuszczenia grzechów popełnionych po chrzcie - nie głosi Tle jednorazomej pokuty, ale druga pokute boenitentia secunda, jak u Tertuliana/. Ták twierdzili: A. d Alès, J.Stufler, P.Galtier, B.Poschmann, K. Rahner. Stanowisko trzecie, pośrednie, lagodzi skrajności obydwu poprzednich. Jego przedstawiciele podkréslaja, ze Hermas wprawdzie przekamuje rygoryzm swo1ch czasów, ale tez w znacznym stopniu pozostaje mu wierny, gdyz głosi pokutę na ścisle określony czas/teoria jubileuszu/; trudno téz dopatrywać się w "Pasterzu" jakiejé sformalizowanej praktyk1 pokutnej, gdyz głównie jest tam mowa o potrzebie nawrócenta. Podobne poglądy głosili: K.Adam, J.Hoh, E.Amann, P.Knorz, R.Joly, S.Glet/reprezentuje to stanowisko tylko częsciowo/.

4 Por. P.Knorz, dz.cyt. 53-58, 69-75. 
go pierwszorzędne znaczenie chrystologiczne. Ujmując zatem całoł́ciowo analizowany związek, trzeba sformułowá nastepujace pytan1e: czy 1 na lle nauka o pokucie kształtuje chrystologie, czy moze odwrotnie, chrystologia stanowi niezbędne założenie nie tylko dla wezwania do pokuty, ale rómniez dla związanych z nia pouczeń moralnych Hermasa?

Nowego znaczenia w tym kontekście nabiera kwestia genezy 1 charakteru hermasowej nauki o pokucie, gdyz zagadnienia tego nie moźna pominąć w dociekaniach chrystologicznych. Pytamy więc o źródło kerygmatu pokutnego "Pasterza": czy było nim nauczanie lub praktyka gminy rzymskiej przełomu I 1 II $w . ?$ Czy 1 na 1 le sam Hermas przełamuje dość powszechnie panujący wtedy rygoryzm " Kościele? Do jakiej tradycji należałoby odnieść jego pouczenia, jako do najblizszego źródła inspiracji? Rózne padały odpowiedzi na te pytania. Dość często sam termin "pokuta" narzucal autorom fałszywe przedrozumlenie mýsli Hermasa, jakby chodziło tym dziele o jakąś formę sakramentu pokuty. W tej zaś kwestil odzywały sie tradycyjne kontrowersje katolicko-protestanckie, co dodatkowo zaciemniało obraz sprawy. Aby uwolnté naukę Hermasa od konfesyjnych 1 zawęzaJących interpretacji, trzeba znacznie bardziej unydatnić jej genezę. Po tej linii idzie St. Giet ${ }^{5}$, którego dociekania 1 sugestie w tym zakresie zasługują na uwag̨, chociaż nie przyjmujemy jego teorif o trzech autorach. Wykazuje on, ze pokute w "Pasterzu" należy rozpatrywać w ścisłym powizzaniu z eschatologią tego dzieła, a zwłaszcza z tradycję późnego judaizmu ${ }^{6}$. Jezeli dalsze badanta po-

5 Por. S.Giet, Hermas et le Pasteur, Paris 1963. Pokucie poświęcil wprawdzie wiele miejsca, ale rozpatruje to zagadnienie w swietle teorii o trzech autorach "Pasterza". Na tym przykładzie widać właśnie słabość tej teori1, gdyż nauka o pokucie jest jednolita w całym dziele Hermasa, a S.Giet próbuje Ja za wszelk: cenę nagią́ do swojej teori1 - por. s.123-133, 174-177, 189-194, 229-234. Ale poza tym jego praca posiada znaczne walory.

6 Tanze, 129-134 /odrzuca podtrzymywaną przez R.Joly teorie jubileuszu/. 
twierdza rezultaty uzyskane przez St.Gieta, to wtedy równiéz teoria - judeochrześcijańskim pochodzeniu "Pasterza" zostanie wzmocniona - dodatkowe argumenty. Oczywície, będzie to miało z kolei podstawowe znaczenie dla interpretacji chrystologii tego pisma.

Hermasowe wezwanie do pokuty odnosi się do Kościoła rozumianego jako zgromadzenie wiernych, śwįttych 1 sprawiedliwych żyjących w doczesności. Posiada więc ono wyraźnie określony fundament eklezjologiczny. Ale e k 1 e z $J 010 \mathrm{~g} 1$ a "Pasterza" nie ogranicza sie do tego. W całym dziele posiada ona znacznie szerszy zakres 1 daleko większe znaczenie. Obejmuje bowiem refleksję nad preegzystencją Kośctoła, nad jego budową w tym świecie, aź po wizję Kościoła nieblańsikłego, eschatologicznego. Z kolei inne vątk1 doktrynalne, w mniejszym lub większym stopniu, zostały podporzędkowane eklezjologi1. Do takiego wnlosku dochodz1 w swo1m studium L. Pernveden ${ }^{7}$. Uwaza on, że właśnie eklezjologia stanowi centralny temat w "Pasterzu", wyprowadzajace z tego wazny dla nas wniosek, iź Hermas nie tworzył chrystologii dla niej samej, ale ze względu na eklezjologię. Dlatego teź nie możemy oczekiwać od niego usystematyzowanej chrystologil, choć mozemy się spodziewać, ze przedstawi on takie koncepcje chrystologiczne, które majaz szczególny wpływ na eklezjologię ${ }^{8}$. W konkluzj1 formułuje L.Pernveden niezmiernie wazna tezę: "chrystologia Hermasa jest eklezjologiczna, a ściśle mówiąc eklezjocentryczna" ${ }^{9}$. Rozwijając dalej tę myśl w płaszczyźnie metodologicznej, moźna by powiedzieć, ze eklezjologia tworzy " "Pasterzu" horyzont hermeneutyczny dla pozostałych tematón oraz pełni wobec nich rolę zasady integrującej. W ten sposób otrzymujemy nie tylko nowe naświetlenie wielu złożonych problemóm, ale ponadto uzyskujemy klucz do interpretacji zagadnień chrystologicznych. Po określeniu miejsca 1 Punkcji eklezjolog11 n strukturze dzleła Hermasa, trzeba rómnieź odpowiedzieć na pytanie dotyczące

7 The Concept of the Church in the Shepherd of Hermas, Lund 1966.

8 Tamze, 70 .

9 Tamie, 71: "The Christology of Hermas is then ecclesiologically or perhaps more precisely ecclesio-centrically determined". 
jej genezy 1 charakteru doktrynalnego. Hi tym zakresie bogatego materiału do dalszych analiz dostarozyl1: J.Audet ${ }^{10}$, P.Knorz ${ }^{11}$, J.Dantélou 12 St.Giet ${ }^{13}$. Niezaleznie od całkowicle odmiennego podejścia do tego zagadnienia, mynikającego z przyjętych załozeń metodologicznych, wykazuja oni ścisłe powiłzania idei eklezjolog1cznych zawartych " "Pasterzu", zwraszcza nauk1 o preegzystencj1 Kościoła z teologia późnego judaizmu. Wskazuja również na podobne koncepcje w literaturze judeochrześcijaŕskiej. Z kolei L.Pernveden zwraca uwagę na istotne różnice, jakie zachodzą pomiędzy nowotestamentalną 1 hermasowa eklezjologia ${ }^{14}$. W Nowym Testamencie Kośció jest f́ciśle zwiazany z Chrystusem 1 Jego dzlełem zbawczym, zwaszcza ze smierciz 1 zmartwychwstaniem. W "Pasterzu" natomiast uderza brak tego jasnego powi tzania - co wiecej, autor nawet nie wspomina o misterium paschalnym Pana. Czyz nie mamy tutaj do czynienia z Jedyną w swoim rodzaju refleksja eklezjologiczną? Istnieją poważne dane, aby sądzić, ze u podstạ rozumienia Kościoła " "Pasterzu" legla qumrańska koncepcja wgpólnoty eschatologicznej, a waźdym razie eklezjologia tego pisma wykazuje zdumiewająca niezalezność od nauki nowotestamentalnej. W przeciwieństwie do Nowego Testamentu, w którym chrystologia w znacznym stopniu warunkuje eklezjologię, w dziele Hermasa mamy wyraźnie do czynienta z zależnościa przebiegająca " kierunku odwrotnym.

W ścisłym powiązaniu ze wspomnianą powyżej relacją: eklezjologia - chrystologia, nalezałoby rozpatrywá p n e u m $t$ o $1 \circ g 1$ "Pasterzan'15. Bez niej ani eklezjologia, ani chrystologia nie moga być właściwie ujęte, a ich wajemna relacja - po-

10 Por. J.Audet, Affinités littéralres et doctrinales du Manuel de Discipline, "Revue Biblique" 60/1953/41-82.

11 Por. P.Knorz, dz.cyt. 76-94.

12 Por. J.Daniélou, Théologie du judéo-christianisme, Paris 1958, 317-326.

13 Por. S.Giet, dz.cyt. 38.

14 Por. L.Pernveden, dz.cyt. 108-121, 169-173, 228.

15 Por. H.Op1tz, Ursprtinge Prthehristlicher Pneumatologie. Ein Beitrag zur Entstehung des Lehre vom Heiligen Geist in der romischen Gemeinde unter Zugrundlegung des I Clemens - Briefo und des "Hirten" des Hermas, Berlin 1960; J.P.Martin, Espiritu y dualismo de esplritus en el Pastor de Hermas y su relatión con el judaísmo, vCh 15/1978/ 295-343. 
dobnie jak cała problematyka doktrynalna tego pisma - uzyskuje dzięk1 pneumatologi1 nieodzowną perspektywę wertykalna, jakby trzec1 wymlar. Cała treść "Pasterza" Jest nasycona pneumatolog1z: Duch Swięty występuje najpierw w preegzystencji jako stwóroza moc Boza 1 Jako Syn, następnie ukazany jest jako dar dla człowieka 1 s1lá moralna, a otrzymuje Go całe zgromadzenie sprawiedliwych 1 świętych - Kościół, fest darem dla "wybranego ciała" - Sługi Bozego. Sam termin "pneuma", w różnych znaczeniach, złozeniach 1 Punkcjach, występuje w tekście "Pasterzan ponad 100 razy 1 naleźy do najczęściej uzywanych terminów, obok theos, pisteuein, pistis, metanoia ${ }^{16}$. Wszystko to świadczy o duzym, a równoczé́nie róznorodnym znaczeniu pneumatologii w dziele Hermasa, oo z kolei musi rzutowác równiez na rozumienie jego chrystologii. W tym tez kierunku zmierzały nowsze badania, na które tutaj się powoływalí́my.

Na tej samej linil dociekań nalezałoby umieścić a $\mathrm{g}$ e 1 o. 1 o 1 e "Pasterzan"17. Nie stanowi ona wprawdzie odrębnego 1 samodzielnego tematu w tym dziele, pełni jednak wim waźn̨ funkcję. Z podobnym zjawiskiem spotykamy się nader często w apokaliptycznej literaturze judaistycznej 1 judeochrześcijańskiej. Rodzi sie tutaj potrzeba studium porównawczego, które pozwoliłoby wydobyé zarówno typowe, Jak 1 oryginalne cechy hermasowej angelologi1. Zwłaszcza zaś - do czego powrócimy w drugim punkcie - szczegółowych badaŕ domaga się związek angelologii z chrystologia. Nie bez znaczenia dla interesujacego nas tematu pozostaje rómnieźzawarta w "Pasterzu" a $n t r \circ p \circ 1 \circ g 1 a^{18}$. Scíllej biorac, chodziłoby o odsłontęc1e pewnych załozeń antropologicznych, które legły u podstáw Ideałów moralnych Hermasa, zwłaszcza nauki o zamieszkiwaniu Ducha Bożego człowieku, które teź warunkuja poprawne rozuniente dualizmu zawartego w jego dziele oraz - co dla nas najwazniejsze - samej osoby 1 dzieła Syne Bożego. Krótko mówiąc, należałoby odpowiedzied

16 Por. J.P.Martin, dz.cyt. 298-308 /analizy semantyczne\%.

17 Por. literature $n$ notach 24-34.

18 Por. P.Knürz, dz.cyt. 1-52. 
na pytanie, z Jaka wizja człorieka mamy do czynienia w "Pasterzun: starotestamentalno-semicka, czy jakąśs hellentstyczną, a może nawet

z obiema razem? Istnieja powazne racje, aby przyjać pierwsza ewentualność, tym niemniej całe to zagadnienie musi być wnikliwie rozpatrzone w dalszych badaniach.

z krótkiego przeglądu problematyki doktrynalnej "Pasterza" można wyciągnąć k1lka wnlosków odnośnie badań chrystologii tego pisma. Najpierw trzeba stwierdzić, ze wątki chrystologiczne są róznorodnie powiazane z głownymi tematami, które Hermas rozwija - stąd okrélenie miejsca 1 funkej1 chrystologil w cazym dziele posiada duze znaczenie dla systematycznych badań samej chrystolog11. Z kole1 należy podnieść fakt, ze problematyka doktrynalna "Pasterza" wykazuje szczególne powinowactwo z myślą późnego judalzmu 1 daleko 1dąca niezalezność od Nowego Testamentu ${ }^{19}$, co skłania wielu uczonych do określenia tego dzieła jako judeochrześcijanskie. Na tej podstawie moźna wysunąc hipotezę, ze również chrystologia "Pasterza" posiada charakter judeochrześcijańsk1. Hipoteza ta zakłada odpowiednie rozumienie teologii judeochrześcijańskiej o oǵ́lności, a w tym równiez odpowiednio uściślone 1 uzasadnione określenie chrystologii judeochrześcijańskiej. Potrzebne sa tutaj bez wątpienia dalsze precyzacje metodologiczne, do których jeszcze powrócimy. Podstawa jednak 1 warunkiem mszelkich dociekań nad charakterem cnrystologil "Pasterza" musi byc wpierw gruntowna jej analiza.

\section{Główne koncepcje chrystologiczne}

Jako punkt wyjśc1a przyjmujemy szerokie rozumienie samej ohrystologi1, a nie zacieśnione do jakiegoś jednego tylko nurtu czy okresu historycznego, albo bazujące na jakimś wybranym z góry modelu myś-

19 Por. E.Massaux, Influence de l'Evangile de saint Matthieu sur la iftérature chrétienne avant saint Irénée, Louvain 1950, 261283 /widzi dość szeroki wpływ, w tym kilka cytatów/; H.Koster, Synoptische Uberlieferung bei den Apostollschen Vatern, Berlin 1957, 242-256/dowodzi, że nie ma w "Pasterzu" cytatow w 11teratury kanonicznej Nowego Testamentu, 1stnieja natomiast zblizenia treściowe będące skutkiem korzystania $z$ wczéńejszych źródeł/. 
lenia. Nie gposób w tym miejscu szerzej rozwijać tej fundamentalnej kwest11 metodologicznej, pragniemy tylko uwydatnić jej znaczenie dla wszelkich badań w zakresie chrystologii nowotestamentalnej, patrystycznej czy współczesnej ${ }^{20}$. Trzeba wszakże zaznaczyé, ze wasnych dociekaŕ nie ograniczamy tylko do analizy tytułów chrystologicznych, ale wnikamy równlez $\approx$ róznorodne powiazzania Syna Bożego z Bogiem, Duchem Swiętym, dziełem zbawienia 1 Kościołem, które autor "Pasterza" znaczacy sposób eksponuje. Po przeprowadzeniu tak rozumianych analiz - uwzględniając złożony charakter 11teracki samego dzieła - doszlíb́ny do wniosku, źe chrystologie hermasowa mozna przedstawic wostaci kilku koncepcji czy idei wiodacych. Zasadność 1ch treściowego wyodrębnienta oraz zastosowana terminologia, stanowiły główny problem dotychczasowych prób systematycznego ujęcia chrystologii "Pasterza".

Na pierwszym miejscu należałoby wyróżnić ch $r$ y $t$ g 1 I m 1 e n 1 a. J.Dantélou wskazał jakimi drogam1 rozwijaIa się ta postać chrystologil na bazie póznojudaistycznych spekulacj1 na temat Imienia Bozego ${ }^{21}$. Gdy chodzi o "Pasterzan, spotykamy się z szeregiem zróżnicowanych określeń i funkcji Imienta /onoma/ zwłaszcza wizjach 1 Podobieństwie VIII 1 IX. Naleźałoby zbadaé ich genezę oraz poddać analizie $1 \mathrm{ch}$ chrystologiczną treść. Dysponujemy aktualnte szeroką bazą źródłową oraz szeregiem opracowań, które umozliwiają realizację tego przedsięwzięcia. Jest ono jednak bardzo rozległe, gdyz trzeba by uwzględnic teologie starotestamentalną 1 póznojudaistyczna, teksty qumrarískie, gnostyckie, Nowy Testament, a zwłaszcza Ewangelie św. Jana, wczesnochrześcijańskie apokryfy 1 dzieła OJców Apostolskich ${ }^{22}$. Juz z tego wyliczenia wys-

20 Por. R.H.Balz, Methodische Probleme der neutestamentlichen Christologie, Neukirchen 1967; W. Harrington, Teologia bibijuna, t1. J.Marecki, Warszawa 1977, 149-236; Jezus Christus/Chr1stologle, w: Neues Handbuch theologische Grundbegriffe, hrsg. von P. Elcher, Munchen 1984, Bd. 2, 226-256; z niewłaściwym określeniem chrystologii spotykamy sie Encyklopedii Katolickiej/III 304/, gdzie została ona utozsamiona z treścią Objawienia na temat Jezusa Chrystusa.

21 Por. J.Daniélou, dz.cyt. 199-216.

22 Por. H.Bletenhard, onoma, TWNT V 242-269; J.Panthot, La s1gnifleation religieuse du "Nom" chez Clément de Rome et dans la Didaché, EThL 35/1959/339-361; A.M.Besnard, Le mystère du nom, 
tarozajaco jasno wynlka, ze chrystologia Imienta jawi sie jako wazny temat w badaniach nurtów ohrystologicznych plerwotnego ohrzedc1janstwa. "Pasterz" Fermasa dostareza nam waenie tej dziedzinto eonnych danych, swiadczagjoh o zywotnoficl tej archaicsnoj chryato$\log 11$ w Godow18ku rzymsks.

W bolskyn powlazandu g angelologia trzeba rozpatrywá problem

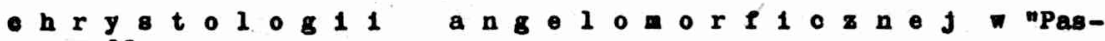
terzum ${ }^{23}$. Dyskusja dotyozy moklimosol ohrystologicznej interpretaoj1 postaol anjoła Miohała, zwanego rónnies aniołem wspaniałym, ohwalebnym, najéwiętzzym. W naszej rodzimej literaturze teologicznej zagadniente to omawiało juz dwóch autorów: E.Stantek 24 F.Szulo ${ }^{25}$. Nalezałoby postulować poszerzenie badar na oały nurt chrystologil angelomorficznej, co pozwolizoby lepiej naśletlić to zagadnienie - dziele Hermasa. Zwróćny uwage na najbardziej reprezentatywne opracowania tej chrystologil, w których zreszta odnajdujemy sporo Informacj1 równiez na temat chrystologii angelomorficznej w "Pasterzu".

Na początku lat ezterdziestych ukazały sie jednoczéńe dwie obszerne monografie poświęcone genezie 1 rozwojowi chrystologil angelomorficznej wierwotnym chrześcijaristwie ${ }^{26}$. M.Werner wyprowadzał te chrystologie z postaci Syna Człowieczego w Księze Henocha 1 uwazal ja za najstarsza 1 najbardziej pierwotna postá́ chrystologi1; usiłował rómniez dowodzić jej decydującego wpływu na chrystologie nowotestamentalna. C.Barbel natomiast upatrywał jej źódło - późno zydowskich spekulacjach nad postacia anioka Jahwe/malak Jahwe/ 1 ukazał jej rozwój w źródłach patrystycznych. $z$ tezami

Paris 1962; F.G.Untergassmair, Im Namen Jesu. Der Namensbegriff Im Johannesevangel1um, Stuttgart 1973 /odporiednie porónnania z Evangelium Veritatis 1 Odae Salomonis/.

23 Termin ten jest tłumaczentem określenia francuskiego "la ohristologie angelomorphique"; inne nazwy: Engelchristologie/niem/, angel-Christology 1 angelomorphio Christology /ang./.

24 Angelologia ". "Pasterzu" Hermasa, STV 9/1971/ 51-82.

25 Por. Struktura teologil judeochrześcijaŕskiej, Lublin 1982, 128-132.

26 Por. M.Werner, D1e Entstehung des chr1stlichen Dogmas; Bern 1941 /wersja skrócona: Stuttgart 1959/; C.Barbel, Christos Angelos, Bonn 1941. 
M. Wernera polemizowal W.Michael1s, wykazując mu zbyt daleko 1dace ekstrapolacje, a zwaszcza niemoznó́ć nyprowadzenia niemal calej chrystologil nowotestamentalnej z ide1 Syna Człowieczego 27. Zagadnienie to zostało z kolei podjete w szerszym kontekście rozwazar nad początkami nauk1 o Trójcy Świętej. Zarówno G.Kretschmar, Jak 1 J.Daniélou dowodzili, ze plerwsze próby dociekań w tym zakresie zostaly podjete przy uzyciu angelologii jako specyficznej kategor11 spekulatywnej ${ }^{28}$. W badaniach tych uczonych chrystologia angelomorficzna została umieszczona we waściwym jej śodowisku zyciowym/S1tz im Leben/, którym było judeochrześcijanstwo. Dz1ęk1 wspomnianym tutaj pracon chrystologia angelomorficzna zdobyła sob1e prawo obywatelstwa wistoril chrystologil nie tylko jako jej heterodoksyjny margines, ale jako wazny doktrynalnie nurt 1 etap rozwojowy pierwotnej chrystologi1 29 .

W tak nakreślonym kontekścte należałoby z kolei anaízować zawiły problem relacji pomiędzy: Synem Bożym, Michałem, aniołem mspaniałym w róznych partiach tekstu "Pasterza". Dość długo utrzymywała sie opinia, ze mamy tutaj do czynienia z jedna postacia, która wprawdzie nosi różne imiona, ale która należy identyfikowá́

z Chrystusem. Te interpretaoje ugruntowaky nauce dwa wielkie autorytety: M.Dibelius 1 J.Lebreton ${ }^{30}$, a pónín rómnież J.Daniélou ${ }^{31}$. Trzeba Jednak tutaj zaznaozyé, ze stanowisko tego ostatniego prowokuje do dyskusji głómnie z tej racj1, ze interpretuje on chrystologie Hermasa przez pryzmat Logosu, wskutek ozego wtłacza ja w obcy jej schemat myslowy. Idea Logosu nie występuje zupeznie $\square$ tekśce "Pasterzạ" - co więcej, Hermas rozwija wrasna chrystologie w opar-

27 Por. W.Miohaelis, Zur Engelohristologie 1m Urohristentum, Basel 1942.

28 Por. G.Kretsohmar, Studien zur fraohristlichen Trinitatstheologie, Tubingen 1956; J.Daniélou, dz.oyt., 167-198.

29 Por. J.llébaert, dz.cyt. 150-157; R.N.Longenecker, dz.cyt. 26-32.

30 Por. M.Dibelius, Der Hirt des Hermas, Tubiggen 1923; 572-576; J.Lebreton, Histolre du dogme de la Trinite, Par1s 1928, t.2. 651-659.

31 Por.J.Dantélou, dz.cyt. 171-177/Le Verbe et Michel $/$. 
ciu o model pneuma - sarks, do czego jeszcze powrócimy. Z drugiej strony krytyka stanowiska J.Danlélou dokonana przez St.Gieta równiez nie przynosi pozytywnego rozwiazania problemu ${ }^{32}$. Wydaje $81 e$, ze N celu osiagnięcia bardziej przekonujących rezultató nalezałoby przezwycięzć alternatywe: albo identyeikacja, albo zupezne rozrózniente. Ta waśnte droga podązaja w swojch badaniach autorzy $z$ ostatnich lat, którzy jednocześnie dostarczają nowych metod do. interpretaoj1 złozonych powiazań hermasowej chrystologil z angelologia $^{33}$. Daje to podstawe do brontenia wcześniej wyrazonej przeze mile opinil, ze "Pasterzu" mamy do czynienia ze specyeiczna ohrystologizacja postaci Michała anioła ${ }^{34}$.

Za trzecią koncepcje chrystologiozną Hermasa, która zasługuJe na specjalne wyrózntenie, trzeba uznać c h r y s to $10 \mathrm{~g} 1$ e p $n \in u m a t \circ 1 \circ g 10 \mathrm{z} a^{35}$. Nalezy ona do najbardziej trudnych 1 spornych kwestil, a czym swiadczy cytowana wcześniej literatura na temat pneumatologil "Pasterza". Zasadnicze trudnosci wynikały głównie stąd, ze usiłowano uzgodnić naukę zawartą "Podob1eństw1e $V$ zauką nowotestamentalna 1 późniejszą doktryną trynitarna. A było to niezwykle trudne, gdyz myśl Hermasa nie poddaje sie latwej klasyfikacji z uwagi na swój wyjątkowo oryginalny charakter. Wystarczy tutaj przywołać odpowiednie teksty, aby się o tym przekonać.

- Podobieństwie V Pasterz opowiada Hermasowi przypowieść o. winnicy. Oto pan /despotes/ oddał w opieke swoją winnicę wiernemu słudze/niewolnikowi - doulos/ nakazując mu tylko ogrodzic ja płotem. Za to miał on otrzymać wolność po powrocie pana. Sługa níe tylko ogrodzlł winnice, ale nadto oczyścił ją z zielska 1 przekopał. Gdy pan powrocił, ucieszył sie z pracy sługi, przywołał msyna swego

32 Por. S.G1et, dz.cyt. 2281239.

33 Por. L.Pernveden, dz.cyt. 58-62; G.F.Snyder, The Shepherd of Hermas, Camden 1968, 60-62; H.Moxnes, God and His Angel in the Shepherd of Hermas, "Studia Theologica" 28/1974/49-56.

34 Por. F.Szulc, Struktura teologil judeochrześcijańskiej, dz.cyt. 130-132.

35 W literaturze teologicznej spotykamy rózne nazwy dla tej koncepoji: la christologie pneumatologique/bąd́ pneumatique/, Pneuma-Christologie, Spirit Christology - nizej nota 44. 


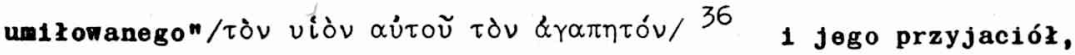
a następnie oznajmił $1 \mathrm{~m}$, ze postanowił nie tylko obdarować sługe wolnościa, ale ponadto uczyníc go współdziedzicem swego syna. Z kolel syn pana zgodzil się na to, aby sługa stał się jego współdzledzicem /V 2,8/. Nieco dalej Pasterz daje wyjaśniente całego opowiadania oraz tłumaczy znaczenie poszczególnych postaci: "Pan pola to Ten, który wszystko stworzył, 1 urządził 1 umocnił. Syn zaś to Duch Swięty, a sługa to Syn Bozyn37. Istotnym dopełrientem tego stwierdzenia jest wytłumaczenie dlaczego sługa stał się współdzledzicem: "Duchowi Ŝlętemu przedwiecznemu, który stworzył całe stworzenie, Bóg dal mieszkanie w clele/sarks/ przez siebie wybranym. Otóz to ciało, w którym zamieszkał Duch Święty, słuzyło Duchow1 znakomicie, bo postępowało drogą świętośc1 1 czystośc1 1 najmniejsza plamą Ducha nie dotknęłon ${ }^{38}$.

Przytoczone teksty były bardzo róznte interpretowane. Niektórzy twierdzil1, ze $w$ teologil Hermasa Bóg posiada dwóch Synów: Ducha Swiętego, którego naleźałoby nazwać Synem w sensie ścisłym oraz Chrystusa, który jest Synem przez adopcję ${ }^{39}$. Z tym wiązały się $z$ kolei powazne trudności natury doktrynalnej. I tak jedni dowodz111, ze mamy tutaj do czynienia z ewidentnym adopcjonizmem, inni znów bronili ortodoksyjności poglądów chrystologicznych Hermasa 40 . Nie mniejsze kontrowersje powstały wokół sformułowania "duch - cia1o". Obydwa elementy interpretowano bądź to w płaszczyźnie antropologicznej, tłumacząc ten sposób byt Chrystusa, bądź też ujmowano Je Punkcjonalnie, rozpatrując $1 \mathrm{ch}$ rolę dziele zbawczym Syna Bozego ${ }^{41}$. Nie sposób tutaj, nawet w znacznym skrócie, przedstawić ponad

36 Pastor. Similitudo V 2,8, SCh 53 b1s, 228, POK 1,364.

37 Tamze, v 5,2, SCh 53 bis, 234-236, POK $1,369$.

38 Tamte, V 6,5, SCh 53 b1s, 238, POK 1,370-371.

39 Por. A.link, dz.cyt. 29; P.Knorz, dz.cyt. 74; H.Opitz, dz.cyt. 79.

40 Ewidentny adopcjontzm zarzuca Hermasowi s.Giet, dz.cyt. 223; natomfast J.Daniélou, dz.cyt. passim, określa tę chrystologię Jako archaiczna.

41 Por. A.Link, dz.cyt. 29: "der Sohn Gottes im engeren Sinne, der tritt an die Stelle der ganze Person /.../, die Sarks erscheint als eine Acc1dens"; przeciwnego zdania jest A.Ribagnac, dz.cyt. 42: "I'homme Jésus, qui sous la conduite du Saint-Bsprit, travaile se ratigue $/ . . . /$, c'est bien lui le veritable racteur de la Rédemption". 
stuletniej historil interpretacji tego fragmentu "Pasterza" 1 zawartej w nim chrystologi1. To temat do odrębnego studium, które powinno siq znaleźć $n$ przyszłej monografil na temat chrystologil tego pisma. Juz teraz jednak trzeba zaznaczyc, ze 1stotny przełom w interpretacji tego tekstu dokonal sie dzięki mprowauzentu do badań literatury wczesnochrześcijańskiej metod histori1 tradycji 1 histori1 redakcj1. Dzięki zastosowaniu tych metod mozna przezwyciezzyć trudności 1 błędy niektóryci rozwiązań tradycyjnych, bazujących na interpretacjach o charakterze ahistorycznym 1 ontyczno-statycznym.

Zgodnie z tymi wskazaniami, zastosowanymi juz z powodzeniem w kilku pracach, nalezałoby szukać dla chrystologii pneumatologicznej Hermasa odpowiednich wzorców 1 załozeń w teologil starotestamentalnej 1 późnojudaistycznej. Podstawowym źródłem inspiracj1 dla późniejszych koncepcj1 chrystologicznych opartych na modelu pneuma sarks była Idea Mesjasza obdarzonego Duchem Jahwe zawarta u Iz 11, 1-9 i 42, 1-9. Była ona rozwijana w późnym judaizmie 1 p plerwotnym chrześcijaŕstie, gdzie została zinterpretowana w duchu eschatologil zrealizowanej 1 odniesiona do Chrystusa ${ }^{42}$. Na tej bazie powstała formuła pneuma - sarks o znaczeniu ścísle chrystologicznym. o jej dość znacznym rozpowszechnieniu świadczy Nowy Testament ${ }^{43}$ oraz 1iteratura wczesnochrześcijańska ${ }^{44}$. Warto przy tym zwrócić uwage, ze w różnych tradycjach 1 u różnych autorów posiada ona nieco odmienne odciente znaczeniowe.

42 Por. M.A.Chevallier, L'Bsprit et le Messie dans le Bas-Judaîsme et le Nouveau Testament, Paris 1958; Duch Swiety - Duch Bozy, praca zbiorowa, red. L.Stachowiak 1 R.ilubinkiericz, Lublin 1985.

43 Por. R.Schnackenburg, Christologie des Neuen Testamentes, In: Mysterium Salutis, III/1, 264-271/analizuje: $\mathrm{Rz} 1,3 \mathrm{n} \cdot ;_{1} 1 \mathrm{P} 3$, 18; $1 \mathrm{Tm} \mathrm{3,16/;} \mathrm{H.} \mathrm{Langkammer,} \mathrm{Hymny} \mathrm{chrystolologiczne.} \mathrm{Najstar-}$ szy obraz Chrystusa, Katowice 1976, 66-79/dotyczy Rz $1,3 \mathrm{n} . /$, 173-177/1 P 3, 18-22/; teuze, U podstaw chrystologil Nowego Testamentu, Wrockaw 1976, 149-158/1 Tm 3,16\%.

44 Por. A.Grillmeier, Jesus der Christus 1m Glauben der Kiroho, Bd. 1: Von der Apostolischen Zeit bis zum Konzil von Chalcedon $/ 451 /$. Freiburg 1979, 158-160 1 200; M.S1monett1, Note di oristologia pneumatica, "Augustinum" 12/1972/201-231; P.J. Schoonenberg, Sprit Christology and Logos Christology, "Bijdragen" 38/1977'/350-375; Y. Congar, Pour une christologie pneumatologique, RSPhTh 63/1979/435-442; L.F.Ladaria, Cristologia del Logos y cristologia del Espiritu, "Gregorianum" 61/1980/ 353-360. 
Dopiero na tak zarysowanym tle gruntowna analiza tekstu "Pasterza" moglaby wydobyć mszystkie osobliwości koncepcji hermasowej, zawartej w Podobieństwie V. W tym zakresie nalezałoby uzupełnic dotychczasowe prace poświęcone bezpośrednto temu zagadnieniu ${ }^{45}$. Wydaje się, ze nauka Hermasa odzwierciedla wczesne stadium tworzenia się chrystologil pneuma - sarks, na co wskazuje cała specyfika połączenia Ducha Bożego z postacia sługi Jahwe w "Pasterzu". Opinie tę formułujemy jako hipotezę do zweryfikowania w dalszych badaniach. Trzeba jednocześnie stwierdzić, ze Hermas bazuje na dobrze ugruntowanej tradycji 1 na swój sposób ją przekazuje. Natomiast jego wasnym dziełem było posłuzenie się tą tradycją do pneumatolocicznej interpretacj1 tytułu chrystologicznego "Syn Bozy". Niewątpliwie tytur ten - a nawet mozna tutaj mówić o rozbudowanej koncepcj1 - uzyskaz oryginalne znaczenie przez oparcie go na idel Ducha Swiętego rozumianego jako własny Syn Boga. Co jednak skłoniło autora "Pasterza", aby tym imieniem obdarzyć Ducha Swiętego? Czy na có́ podobnego mozemy wskazac wradycji? Dotąd pytania te nie zostały wogóle postawione. Być może odpowiedź na nie można by uzyskać dzięki szczegółowym badaniom pneumatologil międzytestamentalnej. Zwróćmy jeszcze uwage i na to, że Syn Boży waiele Hermasa zdaje się posiadać typowe cechy, które charakteryzują bardzo wczesną tradycję o Synu Bozym. I to zagadnienie, zupełnie dotąd nie podjęte, domaga się rozświetlenia. Dopiero po przeprowadzeniu tak szeroko zakrojonych badań mozna będzle dokonać pełnej prezentacji chrystologii pneumatologicznej "Pasterza" 1 zarazem odsłonić genezę oraz rozwój mało znanego dotąd nurtu pierwotnej chrystologii.

dla całościowego ujęcia chrystologil "Pasterza" pozostało jeszcze kilka wątków szczegółowych, rozproszonych po całym dziele. Proponujemy zebrać je razem pod wspólnym nagłówkiem: $t$ y $t$ u $₫$ y

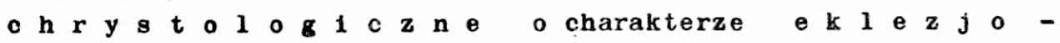
c e $n$ t y c z n y m. o lle można słusznie mówić, ze cała chrystologia Hermasa posiada zasadniczo tę orientację, to w szczególny sposób nalezy tak określić kilka tytuźow chrystologicznych: Pan /Kyr10s, Despotes/, Prawo/Nomos/, Skała/Petra/, Brama/Pylë/.

45 Por. LoCirillo, La christologie pneumatique de la ciaquième parabole du "Pasteur" d'Hermas, "Revue d'histo1re des religions" 93/1973/ 25-48. 
Kazdy z nich jest uzywany przez autora "Pasterza" w kontekście eklezjologioznym 1 w ścisłym powiazzaniu zosolołem.

Interpretacja znaczenia tytułu Kyrios "Pasterzu" nie jest latwa. Najozęściej odnosi się on do samego Boga, wiela innych wypadkach mozna go rozumieć zarówno teocentrycznte, jak 1 chrystologicznde. Jednak przynajmniej $w$ kiku przypadkach tytuł ten odnos1 sie do Chrystusa, zwaszcza gdy występuje w kontekście chrzoielnym ${ }^{46}$. Dalsze badania winny ustalić zakres tego zastosowan1a. Warto tutaj zaznaczyó, ze u Hermasa nie występuje ten tytur * kontekście paschalnym, ale głównie dla podkreślenia roli Chrystusa wobec wspólnoty wiernych. W tym właśnie znaczeniu stosuje autor "Pasterza" tytuł despotès - Pan wieży ${ }^{47}$. W obydwu zatem mypadkach mamy do czynienia z wyraźną orientacją eklezjologiczną.

Podobnie interpretuje Hermas tytuł chrystologiczny "Prawo": Syn Bozy jest prawem dla swego ludu ${ }^{48}$. Hipostazowanie Thory znane jest w Judaizmie 49 , a wezesna literatura chrześcijaŕska zawiera kilka interesujących przykładów nomos-chrystologi1 z powołaniem się na testimonium Iz $2,3^{50}$. Nauka Hermasa mieści się więc $\mathbf{m}$ nurcie dobrze ugruntowanej tradycji, choć 1 tym przypadku je, oryginalność nie podlega dyskusji. Wpierw należałoby porównać hermasowà nomos-chrystologie z Ewangelią Mateusza 1 nauką ów. Pawła. Okazuje a1ę, ze nie rozwija on swojej nauki an1 w duchu chrześcijańskiego rabinizmu Mateusza, ani w duchu pawłowej nauki o Chrystusie nowym praw $1 e^{51}$. Nie ma " "Pasterzu" zupełnie - tak charakterystycznych dla tych autorón biblijnych - przeciwstawień "nowego" 1 "starego". Co wi ̨cej, jego pouczenia moralne w Przykazaniach w ogóle nie odwołują się do nauki Jezusa, bazując głównie na Starym Testamencie. Ten moment pomijały dotychczasowe badania, a rzuca on waśnie nowe światło na rozumiente Chrystusa jako Prawa. Otwiera się tutaj nowe pole badań. Chcąc dogłębnie zrozumieć koncepcję Hermasa, trzeba

46 Por. Visio III 7,3 ; Similitudo VIII $1,1$.

47 Por. Similitudo IX $5,6-7 ; 7,6 ; 9,4$.

48 Por. Simfiltudo VIII 3,2.

49 Por. Starck-Billerbeck, II 353-356.

50 Por. J.Daniélou, dz.cyt. 216-219; R.N.Longenecker, dz.cyt. 41-46.

51 Por. L.Pernveden, dz.cyt. 53. 
uwzględnić ten podstawowy fakt, ze bazuje ona na założeniach pneumatologicznych: Syn Boży jest prawem dla swego ludu jako Ten, który nie splamil mieszkajzcego w Nim Ducha Swįtego. Dlatego tez został on przedstawiony jako wzorzec moralny, przy czym głowny akcent pada na posłuszeństwo Duchowi Swiętemu 1 na doskonała z Nim współpracę. Wynika stąd, ze hermasowa nomos-chrystologia bazuje na jego chrystologil pneumatologicznej, a zarazem jest zorientowana eklezjologicznie poprzez parenetyczne jej wykorzystanie.

Scísle z rzeczywistością Kościoła wiz̨że Hermas Syna Bożego nazywając Go skałą 1 brarąz ${ }^{52}$. Budowa wieży-Kościoła odbywa się na skale 1 ponad bramą ${ }^{53}$. Pojawiający. się Pasterz wyjaśnia Hermasowi, ze włá́nie tą skałą $i$ bramą jest Syn Boży ${ }^{54}$. Na Kim opiera się caza budowla, do której można wejść tylko przez jedną bramę. Znaczące jest tutaj stwierdzenie, ze skała jest prastara, a brama jest nowa. Wydaje się, ze przez połączenie obydwu okré́leń autor "Pasterza" ukazał fundamentalną ciagłość dziejów zbawienia 1 zarazem nowy jej etap. W tym kontekście warto również zapytać, jak widzl Hermas relacje pomiędzy Kościołem a Izraelem? To niewątpliwie wazny oraz interesujący temat dla dalszych dociekań. Nowe naświetlenie tego zagadnienia można by uzyskać odwołując się do symboliki fundamentu 1 budowania, która była rozwijana w Starym Testamencie, 1iteraturze międzytestamentalnej oraz w Nowym Testamen$c 1 e^{55}$.

W podsumowaniu przedstawionej w tym artykule panoramy problemów wypada nam stwierdzić, że chrystologia "Pasterza" jawi sie

52 Similitudo IX $12,1-6$.

53 Similitudo IX 3,$1 ; 4,1$.

54 Similitudo IX $12,1$.

55 Por. J. Szlaga, Symbolika kamienia i fundamentu w Ksiedze Izajasza 28,16-17, "Studia Pelplińskie" 1/1971/149-157; tenź, "Zbudowani na fundamencie apostołów i proroków". Problemy egzegetyczne EP 2,19-22, CT 46/1976/ Pasc.1, 45-65; tenże, Idee teologiczne nowotestamentalnej symboliki fundamentu, w: Materiały pomocnicze do wykładów z biblistyki, III, Lubín 1979, 239-256/tamże szersza bibliograpia/. 
jako zagadnienie zasługujące na szczególne zainteresowanie ze strony badaczy historil dogmatu. Myśl chrystologiczna Hermasa stanowi bowiem cenne świadectwo rozwoju pierwotnej chrystologil w ́rodowisku judeochrześcijańskim. Tworzyło ono wasną kulturę teologlezną w oparciu o kategorie starotestamentalne 1 późnojudaistyczne. Throdowiskach hellenistycznych teologia ta stawała się niezrozumiała 1 jednocześnie niewystarczajaca, gdyz nie była w stanie sprostać nowym problemom, które rodziły się jako skutek spotkania chrześcijaństwa z filozofią grecką. Dalszy rozwój chrześcijaństwa dokonywał się już niemal wyłącznie w łonie cywilizacji grecko-łacińskiej; ona teź dostarczyła podstawowych kategori1 1 pojęc, w których została wyrażona 1 opracowana nauka chrześcijańska; w tym tez duchu pierwsze sobory zdefiniowały nauke Kościoła o Jezusie Chrystusie. Jesteśmy współcześnie świadkami dialogu chrześcijaństwa z innymi kulturami. Pociaga to za soba potrzebeq gruntownego przemyślenia dzłedzictwa przeszłości i szukania nowych form wyrazu dla wiary chrześcijańskiej. Chodzl o wypracowanie jakiejś fundamentalnej hermeneutyki przekładu dotychczasowej doktryny chrześcijańskiej na inne kategorie myśli. Odwołanie się do samych początków rozwoju chrześcijaństma 1 chrystologij moze się okazać niezwykle inspirujące dla tego przedsięwzięcia.

$$
\text { Ks. Franciszek Szulc - Lublin }
$$

\section{INITIATION AUX RECHERCHES SUR LA CHFISTOLOGIE DU "PASTEUR" D'HERMAS /Résumé/}

Cet article a été concu par l'auteur comme initiation aux recherches sur la christologie du "Pasteur" d'Hermas. On y a envisagé deux questions fondamentales. La première est plus méthodologique et concerne le milieu propre de la doctrine do Hermas ainsi que les relations diverses entre la christologie et les autres thèmes doctrinaux: pént tence, écclésiologie, pneumatologie, angélologie, anthropologie, Elle a été analysée dans la première partie de l'article. Les résultats obtenus nous ont permis deconstater deux choses: 1 . le caractére judéo-chrétien de la problématique doctrinale; 2. Ia base pneumatologique et une orientation ecclésiocentrique de la christologie.

Dans la deuxième partie de l'article l'auteur forme un projet de l'élaboration complète de la christologie d'Hermas. On pourrait $y$ distinguer quatre eonceptions principales: 1. 1a christologie du Nom; 2 . la christologie angélomorphique/précisément il s'aglt icl de la christologisation de l'ange Michel/; 
3. la christologie pneumatologique; 4. les titres christologiques ecclésiocentriques /kyrios, despotés, nomos, petra, pyle/. L'auteur montre que toutes ces conceptions tirent leur origine du bas-judaIsme et que la littérature Judéochrétienne contíent de nombreux parallèles de celles-ci. Cet article annonce une étude plus exhaustive de lá christologie du "Pasteur" qui va être publiée dans quelques mois. 